\title{
Depoimento
}

\section{Característica de Walter Benjamin, por Jeanne Marie Gagnebin}

\author{
Ernani Chaves, UFPA
}

\author{
Aproximando-se dele, a ama pôs-se a lavá-lo, mas logo \\ a marca viu, conhecendo-a ... \\ (Homero, Odisséia, Canto XIX).
}

O título deste texto-homenagem é intencionalmente provocativo, pois remete, antes de tudo, ao título do artigo de Adorno - "Charakteristik Walter Benjamins" que guiou, para o bem e para o mal, toda uma corrente interpretativa, que se tornou hegemônica por décadas. "Charakteristik", nos diz, por exemplo, o dicionário Wahrig (1989), quer dizer Kennzeichnung, "assinalação", "marca”, "caracterização". "Característica", segundo o Houaiss, é "traço, propriedade ou qualidade distintiva fundamental". Em alemão e em português, podemos remeter esta palavra as suas raízes gregas, kharaktêr,êros, que significa um sinal gravado ou ainda uma marca. Não por acaso, os sinais, as marcas que trazemos no corpo, como as herdadas geneticamente, são sempre lembradas quando nós mesmos queremos nos caracterizar ou quando os outros querem nos identificar. Mas essas marcas e sinais também podem ser ocasionados por acontecimentos dolorosos, mesmo traumáticos, como uma queda na infância, cujas consequências ficaram impressas definitivamente no corpo. Elas se tornam, assim, cicatrizes. Por isso, à criança que se tornou adulta, elas são mostradas pelos mais velhos como sendo as marcas de sua peraltice e, dependendo da circunstância na qual foram adquiridas, como se fossem medalhas de guerra. Em torno delas, portanto, sempre existe uma história, uma narrativa, contadas, em geral, das mais variadas maneiras. Desde pelo menos a Odisseia, essas marcas estão sempre ligadas à ideia de reconhecimento, por meio das quais alguém é alguém. À sua ama, Odisseu não pode dizer como fez no episódio do ciclope Polifemo, que seu nome é "ninguém", pois a ama, ao contrário do ciclope, conhece a sua cicatriz e por meio dela pode identifica-lo, mesmo que ele esteja disfarçado de mendigo.

Para Adorno, a "característica" de Walter Benjamin, a sua marca distintiva, o sinal que passou a permitir seu reconhecimento, as suas cicatrizes ou como ele mesmo diz, o "seu nome" (uma sutil alusão ao episódio da Odisséia, ao qual acabo de me referir) tornou-se inseparável de sua morte, inseparável do fato de que ele próprio "apagou/extinguiu a sua vida" (sein Leben auslöschte) fugindo dos agentes de Hitler. ${ }^{1}$ Esta circunstância fez dele uma espécie de herói para a geração do imediato pós-guerra, apesar da dificuldade que seus escritos - de "caráter esotérico" nos primeiros trabalhos e de "caráter fragmentário" na obra tardia - colocavam para seus leitores e intérpretes. A fascinação pelo autor e pela obra - esta é em última instância a posição de Adorno - não nos ajuda em nada a compreendê-los, seja o autor, seja a obra. Nessa perspectiva, seu artigo tem a clara intenção de nos fazer ultrapassar esse primeiro plano de leitura, guiado pela fascinação, para que possamos, de fato, poder traçar uma espécie de retrato de Benjamin (no qual, necessariamente, vida e obra se cruzam) mais fiel, mais verdadeiro, para que 
pudéssemos reconhecê-lo pelas suas verdadeiras cicatrizes. Adorno tomava a seu favor, evidentemente, o fato de que conhecera Benjamin e, à sua maneira, se considerava seu amigo, de algum modo se sentindo, naquela ocasião, autorizado mais do que qualquer outro, mais que Scholem e Brecht, por exemplo, a assumir o papel daquele que poderia desfazer os equívocos que se amontoavam em torno do "nome" de Benjamin, de sua vida e sua obra. Independente dos resultados de sua empreitada, cuja grandeza, mas também cuja limitação, a distância histórica nos ajuda a enxergar e compreender, Adorno colocou uma questão crucial: qual a chave de leitura que permitiria adentrar num pensamento, num filosofar que não pode ser mensurado pelo "critério tradicional", uma vez que seu modelo é o "enigma" (Rebus) e seu tema a "reconciliação do mito"?

Retomo esta problemática - e não as possíveis soluções de Adorno - porque ela me parece também ocupar o cerne das preocupações de Jeanne Marie. Mas, não só por isso. Ela me permitirá, por outro lado, retraçar também a trajetória que me levou a estudar Benjamin. Ao contrário do que se imagina e tendo em vista o fato de que fui seu orientando, no período em que cursei disciplinas (1981-1982) no Mestrado da PUC/SP, Jeanne Marie não ofereceu qualquer curso sobre Benjamin. Por isso, não foi sem surpresa que recebi, em janeiro de 1983, em Belém, um pacote que continha seu pequeno/grande livro sobre Benjamin, que acabara de ser publicado na coleção "Encanto Radical" da editora Brasiliense (1982) com uma dedicatória, escrita a lápis em francês, mas ainda hoje bem legível. Assim, minha ligação com Walter Benjamin, mediada por Jeanne Marie, não se iniciou com uma aula, uma palestra, uma conferência ou mesmo uma intervenção, por exemplo, numa banca, ${ }^{2}$ ou ainda pela leitura de um texto do próprio Benjamin, mas pela leitura do livro que ela havia me enviado. Certamente, como todo estudante da época, conhecia Benjamin de nome e de algumas ideias contidas no seu já famoso texto sobre a reprodutibilidade técnica das obras de arte. Entretanto, ocupado com minha dissertação de mestrado e com as atividades docentes que acabara de assumir na UFPA, a leitura do livro não despertou maior interesse de minha parte. Mas, o interesse pelo que minha orientadora publicava, este sim, foi inteiramente despertado. Por isso, passei a guardar, a "colecionar", tudo o que ela publicava e que podia estar ao meu alcance. Acabei constituindo um pequeno arquivo que passou a ser, a partir de 1986, quando Walter Benjamin se tornou "objeto de estudo", meu guia de leitura, de acesso ao seu pensamento (ao de Benjamin, bien sûr, mas também, como posso perceber mais claramente hoje, ao da própria Jeanne Marie). A leitura desses textos foi, sem dúvida, muito mais fundamental do que o impulso mais imediato que conduziu meu interesse por Benjamin: a leitura de Édipo e o Anjo, o livro de Sergio Paulo Rouanet (1981) acerca das relações entre Benjamin e Freud. Depois de uma dissertação de mestrado sobre Foucault e a psicanálise, o interesse pelo livro de Rouanet parecia bastante óbvio. Mas, o caminho em direção ao pensamento de Benjamin foi preparado pela leitura desses textos de Jeanne Marie, hoje pouco conhecidos, quase nunca lidos, raramente citados. Foi deles que extrai a "característica" de Walter Benjamin, que se tornou, em larga medida, a "marca" que a partir de então, o tornou reconhecível para mim.

Gostaria então, neste momento tão especial, momento da mais profunda emoção, quando "o mundo é pequeno aos olhos da lembrança", como escreve Baudelaire em um de seus poemas, retomar esses textos, como se depois de quase três décadas dessa leitura inicial, eu estivesse mais uma vez, sentado numa sala de aula da PUC/SP 3 . São textos publicados entre 1980 e 1985: “A propósito do conceito de 
crítica em Walter Benjamin” (1980), Walter Benjamin: os cacos da história (1982), "As drogas de Walter Benjamin: palavras como vinho" (1984), "Narração e cura" (1984), "Walter Benjamin ou a história aberta" (1985) e "Origem da alegoria, alegoria da origem: uma leitura da Origem do drama barroco alemão" (1985).

A importância desta periodização vai bem além da minha iniciação ao pensamento de Benjamin. Trata-se, principalmente, da entrada de Jeanne Marie na cena filosófica/intelectual brasileira, apresentando para minha geração um Benjamin quase desconhecido. Poderíamos resumir, grosso modo, a recepção de Benjamin entre nós até aquele momento, dizendo que ela se dividia entre a leitura marxista (marcada em maior ou menor grau pelas advertências críticas feitas por Adorno) e a leitura dos diplomatas-intelectuais, como José Guilherme Merquior e Sergio Paulo Rouanet, em que pesem as distâncias que existiam entre os dois últimos. ${ }^{4}$ Mas, tratase também de um momento muito especial da recente história do Brasil, uma vez que coincide com final da ditadura militar e o início do processo chamado de "abertura política". Recém-chegada da Europa, por motivos "pouco acadêmicos", tal como ela mesmo declara na breve notícia biográfica, ao final do livro publicado em 1982, pertencendo, conforme já declarou publicamente em algumas ocasiões, à geração de maio de 1968, Jeanne Marie desembarca num Brasil ainda imerso nos nossos "anos de chumbo". Um Brasil ditatorial que ela também já conhecia pelas conversas e relatos de uma "testemunha" muito especial, Luís Travassos, o militante e ex-presidente da UNE, que havia sido trocado pelo embaixador americano em 1968 e que viveu em Berlim, onde Jeanne Marie o conheceu. Morto num acidente de carro em fevereiro de 1982, com apenas 37 anos de idade, foi à sua memória que Jeanne Marie dedicou seu primeiro livro no Brasil.

Esta dedicatória, profundamente benjaminiana - "Em memória de Luís Travassos que também deixou muitas esperanças a cumprir" - faz parte do livro, o livro de algum modo a explica, ela constitui uma espécie de "imagem dialética", na qual se encontram - enfatizadas pelo "também" - a resistência ao nazismo e à ditadura militar brasileira, Port-Bou, onde Benjamin "apagou/extingiu" a própria vida e o Aterro do Flamengo, no Rio de Janeiro, onde o carro de Travassos capotou. O leitor de hoje, que conhece os textos de Jeanne Marie, não terá dificuldade, portanto, em estabelecer uma ligação entre este primeiro livro e um tema que se imporá ao pensamento dela a partir da década de 1990, qual seja, o da relação entre memória, testemunho e resistência aos regimes totalitários. Reconhecerá também, o tripé que constitui, segundo penso, o solo sobre o qual Jeanne Marie assentará sua leitura de Benjamin, ou melhor, sua "característica" de Benjamin: o teórico ou epistemológico (a reflexão sobre a história, em especial, que repercute sobre o conceito de crítica e sobre o papel da dimensão estética, ambos permeados pela questão da linguagem), o ético e o político. Nesta perspectiva, estes textos de Jeanne Marie, escritos no período que se segue a sua chegada ao Brasil, estão longe de ser apenas textos de uma intelectual europeia que olhava de longe, do alto de sua erudição, a cultura, a história, do país para onde chegou trazida por ventos "pouco acadêmicos". Mas, também, são textos que acompanham, seja na forma de resenhas, seja na de artigos por ocasião de seus respectivos lançamentos, o primeiro "boom" editorial ligado a Benjamin no Brasil: em 1984, quase que simultaneamente, a publicação de uma coletânea de textos sobre o Haxixe e a do Drama barroco alemão, o famoso Trauerspiel-Buch, a tese de Habilitation, recusada pela Universidade de Frankfurt em 1927, com o aval de Horkheimer; em 1985, o primeiro volume das Obras escolhidas, do qual ela escreveu o "Prefácio" e que trazia um conjunto de textos, a

Cadernos Benjaminianos, Número especial, Belo Horizonte, 2013, página 13-25 
maioria inteiramente desconhecida no Brasil. Todos esses livros foram publicados pela mesma editora, a Brasiliense, cujo fundador, Caio Prado Júnior, foi um dos mais importantes intelectuais de esquerda do nosso país. Benjamin parecia estar em casa.

Para esta oportunidade, vou me restringir apenas aos três primeiros textos citados: o artigo publicado na revista Discurso, o livro da coleção "Encanto Radical" e a resenha dos textos sobre o Haxixe. Estes três textos, como procurarei mostrar, já indicam as "características" do pensamento de Benjamin, assinaladas por Jeanne Marie e que o tornaram reconhecível para mim. Eles são suficientes para mostrar o quanto algumas marcas que até então caracterizavam o Benjamin brasileiro vão ser, aos poucos, mas sempre com muita contundência e radicalidade, questionadas por Jeanne Marie.

Desde o primeiro texto, artigo publicado na revista Discurso, do Departamento de Filosofia da USP, Jeanne Marie insistirá na "especificidade da análise literária materialista" de Benjamin, uma "especificidade" que punha em jogo uma ideia, um conceito de tradição cultural, cuja transmissão não significaria apenas a "deformação de um pretenso sentido 'autêntico' da obra", mas, acima de tudo, "a marca do interesse da classe dominante". ${ }^{5}$ A "crítica materialista marxista", ao contrário, não deveria ignorar que não apenas a gênese da tradição é resultado da luta de classes, mas que também a transmissão da tradição diz respeito "a história dos vencedores", da qual nos falam as Teses "Sobre o conceito de história". ${ }^{6}$ Refazendo em algumas páginas o trajeto da concepção de crítica em Benjamin em três textos fundamentais de sua "juventude", a tese de doutoramento, o ensaio sobre As Afinidades Eletivas, de Goethe, e o livro sobre o drama barroco alemão, Jeanne Marie vai mostrar quais os elementos fundamentais desta concepção que permanecerão nos textos ditos "marxistas" ou "materialistas" de Benjamin, para nos mantermos no mesmo plano de divisão de sua obra, vigente na época. Não é por acaso, portanto, que esse primeiro artigo tem seu corolário apontando a "desconfiança" de Benjamin em relação à dialética, tal como os textos tardios sobre Baudelaire o mostram, textos os quais, não por acaso, foram o objeto privilegiado da polêmica, das objeções de Adorno ao trabalho de Benjamin.

Menos que uma análise interna dos argumentos desse primeiro texto - e dos outros listados por mim acima - trata-se, neste momento, de mostrar em que medida Jeanne Marie vai escrevendo a sua "caracterização" de Benjamin. E aqui ressalto pelo menos dois aspectos. O primeiro diz respeito ao fato de que ela não faz uma distinção entre os primeiros escritos de Benjamin e aqueles que se seguirão ao seu interesse pelo marxismo do ponto de vista de sua importância ou ainda de seu lugar na obra, descartando, logo de início, toda tentativa de inferiorizar os primeiros textos por serem metafísicos e de valorizar os últimos, por serem materialistas. Ao contrário, como ela deixará bem claro no livro de 1982, não há uma espécie de "ruptura epistemológica" aos moldes da época, francamente baseados na leitura que Althusser fizera da obra de Marx, entre um Benjamin idealista e outro, melhor, mais verdadeiro e, principalmente, mais eficaz do ponto de vista político, por ser materialista. Para Jeanne Marie, metafísica, idealismo, teologia não são ofensas, não são marcas inferiores, sujeiras a serem limpas. Era, entretanto, preciso afastar da leitura de Benjamin a tentação que ele próprio exorcizou nas "Teses" sobre o conceito de história, quando analisou de forma tão radical a impotência da esquerda alemã em deter o avanço do nazismo, qual seja, a crença no progresso. Assim sendo, 
a obra de Benjamin não evoluiu, não progrediu a partir do momento em que ele entrou em contato com o marxismo. Este, certamente, redimensionou seu pensamento e sua obra, em vários aspectos radicalizou seu pensamento estético e político, mas a obra anterior jamais foi renegada, como o fizera, por exemplo, Lukács. Quem já conhece o mais recente artigo de Jeanne Marie publicado na França, no número especial sobre Benjamin dos Cahiers de l'Herne (2013), ${ }^{7}$ vai perceber claramente que ela se mantém fiel a este princípio. Este último artigo mantém uma ligação insuspeitada com o de 1980, pois ambos giram em torno do conceito de crítica, analisando, prioritariamente, os textos de juventude. Além disso, ambos mostram com bastante clareza e contundência a ligação que existe entre os primeiros textos de Benjamin e os últimos, de tal modo que não podemos compreender a dimensão da crítica nos anos 1930, que aparece nos textos sobre Proust, Kafka, Brecht e Baudelaire, por exemplo, como uma ruptura absoluta e total com a concepção de crítica que vem sendo elaborada desde a tese sobre os românticos. Não se trata, evidentemente, de perseguir uma continuidade monótona e preguiçosa, mas mostrar os impasses, as dificuldades, as tensões não necessariamente resolvidas, que no fundo são apenas os sintomas de um problema, de uma questão, esta sim, "atual”, que se desloca por razões, que são antes de tudo históricas.

Nesta perspectiva, desde a tese de doutoramento, defendida em 1919, na Universidade de Berna, na Suíça, Benjamin se afasta da concepção de crítica que julga encontrar no romantismo, ou seja, a da crítica como "método de consumação" da obra $^{8}$ e em seu lugar a pensa como "julgamento da obra", ou seja, como o reconhecimento de uma ordem que lhe é inerente, uma ordem, entretanto, que a constitui e a desdobra. Oposição, portanto, entre o que se "consuma" e o que se abre, a crítica resultando no "não acabamento" e na "capacidade de transformação", próprias a toda criação artística. ${ }^{9}$ Alguns anos depois, no ensaio sobre As afinidades eletivas, de 1925-1926, Benjamin exercita esta perspectiva, distinguindo na tarefa da crítica o momento da "análise minuciosa do material da obra, material histórico e filológico, portanto datado e efêmero", o que constitui o seu "teor coisal" (Sachgehalt), ao qual opõe o "teor de verdade" (Wahrheitsgehalt) da obra, ou seja, o que transcende a sua finitude e a sua inscrição histórica. Entretanto, se, por um lado, o "teor de verdade" se opõe à finitude das obras, está, por outro, é indissoluvelmente ligado ao seu "teor coisal", uma vez que a verdade só pode ser descoberta no "seio da organização do texto compreendido como uma produção histórica". O "comentário" da obra, resultante deste primeiro momento é assim, ao mesmo tempo, a assinalação de sua historicidade e a afirmação da necessidade de ultrapassar o texto para atingir a sua verdade. Ora, essa dupla condição da crítica, que Jeanne Marie chama, em 1980, de "contradição inerente à crítica benjaminiana"10 se mantém, deslocada por outra rede conceitual e por outro momento histórico, nos textos da fase dita materialista. Trata-se, em última instância, de manter sempre no horizonte da leitura tanto a permanência de questões e problemas ainda não resolvidos, como também os deslocamentos e as rupturas que vão se fazendo no decorrer da obra. Mas, trata-se também e, principalmente, de mostrar a importância da dimensão da historicidade no pensamento de Benjamin.

O segundo aspecto importante a ser ressaltado, que esse primeiro artigo já aponta, é a preocupação de Jeanne Marie com o estado em que se encontrava a recepção brasileira de Benjamin, no que diz respeito ao conhecimento dos seus textos. Se, por um lado, as referências bibliográficas do artigo remetem sempre à edição alemã das

Cadernos Benjaminianos, Número especial, Belo Horizonte, 2013, página 13-25 
obras de Benjamin, o que vale igualmente para os comentadores citados, por outro lado, sempre preocupada com a importância da ampliação do acesso de seus novos leitores brasileiros à obra de Benjamin, ela apresenta, na forma de anexos ao seu artigo, a tradução de dois textos fundamentais: a introdução ao ensaio sobre $A s$ Afinidades Eletivas, na qual se encontra a famosa distinção e correlação entre "teor coisal" e "teor de verdade" das obras, assim como a famosa passagem da carta de Adorno de 10 de novembro de 1938, na qual a versão do ensaio sobre Baudelaire que Benjamin lhe enviara é duramente criticada. Também no decorrer do artigo, já nos deparamos com uma maneira de citar que acompanhará todo o trabalho de Jeanne Marie: ao texto traduzido em português no corpo do texto, segue-se o texto em alemão na nota de rodapé ou ainda tanto o texto em alemão, quanto a tradução brasileira utilizada, como é o caso das referências a Hegel. ${ }^{11}$ Não se trata, de modo algum, de um procedimento retórico no mau sentido da palavra ou ainda num ato de exibicionismo, para evidenciar seus conhecimentos de alemão, como se costuma fazer ainda hoje. Trata-se, ao contrário, de se defrontar, como o próprio Benjamin o fez, com a materialidade da linguagem, confrontação inadiável e incontornável, pois esta materialidade, atravessada pela história, é o "desvio" que devemos tomar para sair do caminho reto e estreito da ideia mais tradicional de método. Uma concepção de filologia que Benjamin esboçara na sua tímida, acanhada resposta às duras críticas de Adorno, que nada tem em comum com a filologia praticada na universidade alemã desde o século XIX e que Nietzsche já criticara tão radicalmente. Uma filologia que não significa a certeza de que a verdade será encontrada na sua luz radiante, mas, ao contrário, aquela que pressupõe, antes de tudo, o desmantelamento dessa ilusão. Uma filologia “a contrapelo". Quem foi ou é aluno, orientando de Jeanne Marie ou mesmo quem é apenas seu leitor atento, sabe bem o que significa esse cuidado filológico: é como se estivéssemos, novamente, aprendendo a ler, como se outra "cartilha do ABC" nos fosse apresentada. Enfatizar a diferença entre Vorstellung (representação) e Darstellung (apresentação), para dar apenas um exemplo, não é uma bobagem acessória, resultado de um exercício tirânico de erudição, ou ainda uma simples aula de gramática alemã, mas a assinalação de uma diferença conceitual, que implica em consequências decisivas para o entendimento da filosofia de Benjamin, como bem mostra o artigo de Georg Otte, também publicado neste dossiê. ${ }^{12}$

Esse primeiro artigo, portanto, já traz consigo as marcas de sua autora, do modo como Jeanne Marie lê Benjamin (e todos os filósofos, críticos literários, com os quais ela se ocupa). Os textos posteriores, como que desdobram, ampliam essas questões, abrem o leque. De cada um deles, escolherei apenas um aspecto para pontuar esse desdobramento, seguindo sempre o mesmo fio condutor, qual seja, a questão "como ler Benjamin".

Correlata à impossibilidade de fazer uma separação rígida e absoluta entre o "jovem" e o Benjamin da "maturidade", está a importância concedida por Jeanne Marie ao papel do judaísmo no pensamento de Benjamin. Desse aspecto, ela se ocupa no capítulo 2 de Os cacos da história (GAGNEBIN, 1982, p.24-40). ${ }^{13}$ Como entender a possível conciliação entre judaísmo e materialismo, se lembrarmos a dissociação entre ambos, que o próprio Marx já parecia ter feito na "Questão judaica"? Como entender que, mesmo em seu último texto, nas "Teses" sobre o conceito de história, Benjamin continue recorrendo, explícita ou implicitamente, às referências teológicas? O que significa, enfim, a presença da "pequena e feia" teologia logo na primeira das teses "Sobre o conceito de história"? Ora, nas poucas

Cadernos Benjaminianos, Número especial, Belo Horizonte, 2013, página 13-25 
páginas deste capítulo, encontramos não apenas um resumo das questões, dos debates eminentemente políticos que assombraram a geração dos jovens judeus alemães das famílias assimiladas em diversos graus, como a do próprio Benjamin. Época do advento do sionismo e do engajamento na Jugendbewegung (Movimento de Juventude), da qual o próprio Benjamin fizera parte e no qual ele conheceu Gershom Scholem. A amizade com Scholem, sabemos, é neste aspecto decisiva, pois é por meio do amigo que Benjamin passa a conhecer, a partir das próprias fontes e da melhor bibliografia de apoio então existentes, tanto a teologia quanto a mística judaica.

Mais uma vez, Jeanne Marie enfatiza o caminho que o próprio Benjamin seguirá em meio a estes debates: desconfia da esquerda socializante da Jugendbewegung, mas participa de sua crítica à sociedade burguesa; posteriormente, hesita em viajar para a Palestina, como o fizera Scholem, mas também nunca consegue se filiar ao Partido Comunista. Estas desconfianças não significam, de modo algum, uma recusa à ação política ou ainda uma imobilidade niilista. Muito pelo contrário, elas se enraízam numa concepção teórica muito contundente, da qual Benjamin extrai os elementos que norteiam sua própria ação política. Jeanne Marie indica isso rapidamente, ao se referir ao pequeno texto de 1920-1921, o "Fragmento TeológicoPolítico" (jamais citado antes na recepção brasileira, diga-se de passagem!), no qual Benjamin critica a ideia de que o Reino de Deus se realizará na terra. Trata-se de criticar a possível coincidência entre o "real" e o "utópico", tal como pretendiam concretizar a qualquer custo os sionistas com o projeto de uma "Nova Jerusalém" ou os comunistas e a sociedade sem classes. O problema para Benjamin é justamente o "a qualquer custo". Ao custo, por exemplo, da tradição cultural burguesa considerada simplesmente como conservadora ou reacionária e mesmo ao custo do reconhecimento da importância decisiva das vanguardas estéticas (no famoso "debate sobre o expressionismo", por exemplo) tal como ele problematizará em tantos textos importantes, a partir do final da década de 1920. O "a qualquer custo", insisto, nos faria esquecer, assinala Jeanne Marie, "a dimensão crítica da ação política". Estamos de volta, portanto, ao problema da crítica, desta feita articulado diretamente com a questão da política. E se fôssemos insistir em desenrolar o fio desta meada, encontraríamos no caminho tanto o hoje famoso "Para a crítica da violência", de 1921, assim como as teses intitulados "Sobre o conceito de história", de 1940.

Mas, em que consiste exatamente, a relação de Benjamin com o judaísmo? De que maneira ele o compatibiliza com a dimensão materialista, marxista, de seu pensamento? A resposta de Jeanne Marie se encontra já no final do capítulo, após ter apresentado o embate de Benjamin com as correntes marxistas de sua época, no campo da estética, seja com Lukács ou ainda com Asja Lacis, aquela por cujas mãos ele conhecerá Brecht. Benjamin, mais uma vez, segue na contramão da teoria marxista da literatura então dominante, baseada na "análise sociológica do meio do escritor e nos conceitos de realismo e reflexo". ${ }^{14}$ Ora, o que Jeanne Marie mais uma vez mostra bem, na sequência do artigo de 1980, é que essa dimensão crítica, por parte de Benjamin, já estava formulada desde, no mínimo, a sua tese de doutoramento sobre o romantismo alemão. Ou seja, antes de seu contato com o materialismo dialético, Benjamin já tinha se afastado da concepção dominante de crítica professada, em especial, na universidade alemã, afastamento que lhe rendeu o fracasso de suaHabilitation. A ciência burguesa da literatura já havia sido criticada duramente por Benjamin, antes de seu encontro com o marxismo. Uma crítica 
centrada na dissociação entre a verdade do texto que a crítica pretensamente deve encontrar e a sua historicidade. Jeanne Marie recorre então a uma carta de Benjamin ao crítico literário suíço Max Rychner, na qual ele fala um pouco do caminho que o crítico deve percorrer para atravessar a espessura da obra a fim não de encontrar sua verdade última, mas, ao contrário, de confrontar-se com sua historicidade, caminho que só poderia ser explicado por meio de uma metáfora teológica: "Nunca pude pesquisar ou pensar senão num sentido, se me atrevo a dizê-lo, teológico - isto é, de acordo com a doutrina talmúdica dos quarenta e nove níveis de sentido de cada passagem da Torá". ${ }^{15}$ A leitura e a interpretação de um texto implicam, por conseguinte, no reconhecimento de uma única verdade possível: a da sua incompletude, a do seu inacabamento, a da sua abertura do sentido. Uma herança que certamente também encontramos em Freud.

O breve parágrafo que se segue a esta citação e que encerra este capítulo é absolutamente precioso para entendermos a questão. Tento dissecá-lo, como que reconstruindo sua estrutura, a partir da tese fundamental defendida pela autora: em Benjamin há uma diferença entre religião e teologia, entre os dogmas e preceitos da religião e a teologia como processo reflexivo que toma a religião como objeto e de quem herdamos um modelo de hermenêutica absolutamente importante e necessário. Uma diferenciação que não surge, evidentemente, com Benjamin, mas que remonta à Aufklärung judaica e ao nome de Moses Mendelssohn.

Assim sendo, é a teologia, antes de tudo, que fornece a Benjamin o modelo de crítica da ciência burguesa da literatura. Mas não qualquer teologia, e sim a judaica. Melhor ainda: não toda a teologia judaica, mas suas correntes místicas, em especial aquela defendida por Isaac Luria. A interpretação da Cabala - da qual a mística de Luria seria o exemplo mais radical - não busca o sentido último, definitivo, unívoco do texto. Pelo contrário, a origem divina de um texto, ao contrário de outras teologias cristãs, não é reconhecida pela existência dessa verdade última (pensemos em Paulo ou em Lutero), mas sim pela impossibilidade de redução do texto a um significado único e último. O comentário da Cabala não é, portanto, o que vai permitir o acesso à verdade última, mas é o exercício, humano, demasiado humano, de preparação para a "profundidade ilimitada" da palavra de Deus, para sua "leitura infinita", que o número místico de 7 ao quadrado, isto é, 49, simboliza. Interpretação, comentário, hermenêutica, texto - todas estas palavras nos remetem, agora sim, em última instância, à dimensão histórica da linguagem após a queda do Paraíso.

O resultado da utilização da tradição mística no contexto de uma leitura materialista dos textos literários é uma "contribuição absolutamente notável", diz Jeanne Marie, uma vez que ela permite ultrapassar os clichês que a crítica materialista insistia em reproduzir, ou seja, em diagnosticar a verdade de um texto como burguês, decadente ou proletário revolucionário. Em seu lugar, a possibilidade de descobrir novas camadas de sentido, até então ocultas, ignoradas, rechaçadas, recalcadas, de um texto. Por isso, Proust não será considerado um burguês decadente, Baudelaire um católico conservador impregnado pelo espírito do simbolismo e Kafka apenas um revoltado niilista. A "verdade da crítica" não consiste, portanto, no fato de que a crítica pode nos restituir a plenitude da verdade na sua origem luminosa, mas, ao contrário, porque ela permite, por meio da interferência da história, trazer à tona camadas de significação ignoradas, recalcados, submetidas, no processo de transmissão dos textos, às estratégias dominantes.

Cadernos Benjaminianos, Número especial, Belo Horizonte, 2013, página 13-25 
Em 1984, na Coleção "Circo de Letras" da Editora Brasiliense, se publica a tradução de Flávio de Menezes e Carlos Nelson Coutinho, de uma coletânea de textos de Benjamin sobre o Haxixe, droga que Benjamin utilizou bastante, algumas vezes como uma espécie de "cobaia" para os experimentos de um amigo médico berlinense, companheiro da época da Jugendbewegung, Ernst Joel. Benjamin escreveu alguns textos sobre o assunto, vários "protocolos", que depois deveriam ser analisados por Joel e mencionou essas experiências em algumas cartas. Jeanne Marie, autora da casa, foi convidada para fazer a resenha do livro para a edição de junho do jornal Leia Livros, uma publicação mensal, iniciada na própria Editora Brasiliense, mas que exatamente a partir de março de 1984, passou a ser publicado pela Editora Joruês.

Esta resenha é o meu texto preferido, dentre os textos que estou analisando aqui. E aqui torno público o motivo dessa preferência, pois se trata de uma "confissão" autobiográfica. Neste mesmo ano, dois meses após a publicação da resenha, ou seja, em agosto de 1984, fui convidado pelo Centro Acadêmico do então Centro de Filosofia e Ciências Humanas da UFPA, para participar de uma mesa-redonda, junto com colegas de outras áreas (Psicologia, Antropologia e Biologia) para participar de uma discussão sobre drogas. Auditório lotado, a mesa aconteceu após uma tentativa de embargo por parte da Polícia Federal, uma vez que devido a Lei Anti-drogas da época, qualquer debate sobre este assunto deveria ter uma autorização da Polícia Federal. Clima tenso, mas com aquele aspecto combativo, libertário, próprio da juventude que estava saindo da ditadura militar. Pois bem: expus, em linhas gerais, um pequeno texto de Benjamin, "Haxixe em Marselha", que eu conhecia numa tradução francesa ou espanhola, não lembro mais exatamente, acompanhado de algumas observações presentes na resenha de Jeanne Marie. Ninguém entendeu direito obviamente, nem eu mesmo entendia bem o enjeu da discussão de Benjamin e do texto de Jeanne Marie. Conclusão: fomos todos processados pela Polícia Federal. E foi uma luta ferrenha para retirar o processo do âmbito da Justiça Militar para a Justiça Comum. Quando eu e Egidio Machado Sales Filho, amigo e advogado, discutíamos os termos da minha defesa, pensamos em anexar o texto de Benjamin e a resenha de Jeanne Marie. Rimos muito (Egidio também conhecia Jeanne Marie, fora seu aluno e seu orientando na PUC), apesar da preocupação, pensando na nossa nobre amiga e professora suiça, que iria acabar nas páginas de um processo na justiça. Processo longo, que demorou vários anos, mas que, ao final, fui absolvido. A defesa continha, de todo modo, um resumo do texto de Benjamin, o contexto filosófico da questão e, sem citar, algumas passagens desta resenha.

A resenha começa desfazendo um possível equívoco que eu traduziria assim: Benjamin não esteve em Woodstock! Ou seja, é preciso entender estes textos no seu duplo contexto, o interno ao pensamento de Benjamin e o externo, ou seja, o lugar destes textos dentro da reflexão filosófica de Benjamin e, ao mesmo tempo, a função da droga nas experiências próprias da concepção de modernidade, a partir da segunda metade do século XIX. A vida e a obra de Baudelaire são emblemáticas em relação a isso. Assim, não se trata de "nenhuma descrição desvairada de efeitos sobrenaturais, nenhuma cena exótica ou chocante, nenhum panegírico, nenhuma justificação da droga" ${ }^{17}$ Em outras palavras, uma coletânea que iria decepcionar os leitores desejosos de reencontrar ali, avant la lettre, a tríade sexo, drogas e rock n'roll. Este ponto de partida é fundamental para que Jeanne Marie possa considerar esses textos como pertencentes ao pensamento de Benjamin, ou seja, eles não são descartáveis, seja por moralismo, seja por insuficiência teórica. Ao contrário, neles 
está presente um traço comum, traço este que é próprio ao pensamento de Benjamin: não se trata de fuga da realidade (tal como o psicologismo moralista diagnostica o uso de drogas), ou seja, fugir do intelecto, da racionalidade para afundar-se num êxtase perigoso e mortal. Do que se trata então? Qual o problema relevante que esses textos expõem? Jeanne Marie responde de forma lapidar: "reencontrar dimensões soterradas ou apagadas da própria experiência do pensar - este pensar que Benjamin no seu ensaio sobre "O Surrealismo" definiu como um 'narcótico iminente'. Ou, em outras palavras, não se busca uma perda, mas, sim, uma ampliação da consciência". ${ }^{18}$ Nesta perspectiva, esses textos sobre o Haxixe acabam-se revelando devedores de um motivo fundamental do pensamento de Benjamin, na medida em que se mostram como plenos de uma autoreflexão, na medida em que estão empenhados em se perguntar quando começa, como acontece e quando termina o efeito da droga. Ora, o que isso tem em comum com o pensamento de Benjamin? É que esse exercício de autorreflexão é feito a partir de uma "constante atitude de observação crítica", na qual se revela o procedimento, metodológico poderíamos dizer, de Benjamin, que provocou tantas reações em contrário de Adorno: em vez da elaboração de uma teoria consistente (na qual as mediações seriam fundamentais!), um pensamento que se elabora ao demorar-se "na observação demorada das configurações concretas e na crítica das várias formas de linguagem". Esta tese forte, contundente, se afirma a partir de duas outras igualmente importantes e que seriam "características" da escrita de Benjamin: 1) a crítica do sujeito soberano, consciente, que "fala de cima sobre as coisas" e 2) este apagamento da soberania do sujeito implica numa outra relação com as coisas, com os objetos, "uma aproximação respeitosa e amorosa dos objetos na sua densidade concreta - que também e histórica e social".

A dimensão da crítica reaparece aqui, implicitamente: a experiência com as drogas pode trazer à luz um modo de se "apropriar" dos objetos, ou melhor, das "coisas" (Sachen), absolutamente diferentes. Trata-se agora, diz Jeanne Marie, de redescobrir uma proximidade "mimética" com o mundo das coisas, "que as crianças, nas suas brincadeiras, ainda sabem" (esta passagem prenuncia outros estudos de Jeanne Marie sobre o conceito de mimese em Benjamin). É o adulto, racional e consciente, quem constrói a relação de conhecimento a partir da separação entre sujeito e objeto, recalcando assim (emprego, de propósito, o conceito freudiano), em nome, justamente, do racional e consciente, a experiência própria às crianças, que fazem da relação com suas coisas, com seus brinquedos, o seu mundo. Se da separação entre sujeito e objeto se constitui o ideal de conhecimento próprio à nossa cultura, seja ele científico ou filosófico, essa aproximação mimética com o mundo das coisas não provoca ao final uma "confusão" ou uma espécie de "identificação primária", na qual nos perdemos nas coisas e com isso perdemos o contato com a "realidade", mas, constitui sim, um saber. Ouso dizer aqui, que Jeanne Marie insinua uma distinção entre conhecimento (científico ou filosófico) e saber. O saber possui uma característica "sensual" e com isso, a "materialidade" própria às coisas não se perde. O saber pressupõe, portanto, não uma adequação da coisa ao intelecto, mas, ao contrário, uma aproximação entre a coisa e o intelecto. Uma aproximação, na qual os procedimentos racionais podem reconhecer o que devem a esses encontros sensuais, aproximação na qual o indivíduo ou ainda a pessoa, dão lugar ao sujeito cindido, dividido, que a leitura de Freud, intensificada no final dos anos 1920, mostrara a Benjamin. Não se trata nem de uma ode ao espontaneísmo, de uma retomada por outros meios de um vitalismo, muito menos de cair no abismo do 
irracionalismo, mas de apostar tanto no que há de irremediável quanto de derrisório nesta aproximação, sempre arriscada, com a materialidade das coisas. Neste espaço, a linguagem assume um papel primordial, pois é ela e sua capacidade mimética, uma espécie de facilitadora dessa aproximação. Não por acaso, o subtítulo da resenha se chama "palavras como vinho", para relembrar uma das anotações de Benjamin consignada numa de suas trips: "Gostaria de escrever algo que viesse das coisas como vem o vinho das uvas". O haxixe, portanto, nos faz descobrir a materialidade da linguagem, ou seja, ele opera "uma espécie de transfiguração que leva à descoberta de camadas subterrâneas e vivas da matéria e da linguagem".

A resenha termina com a indicação dos diversos erros, equívocos e incompletudes da tradução, que expressam a preocupação que já apontei anteriormente, por parte de Jeanne Marie, em não apenas ampliar o acesso dos estudantes e pesquisadores brasileiros aos textos de Benjamin não traduzidos, mas também de apresentar e zelar por traduções confiáveis. Do ponto de vista dela, este não era exatamente o caso.

A resenha sobre o Haxixe abre ainda mais o leque das perspectivas abertas pela interpretação de Jeanne Marie. Desta feita, não apenas porque ela mostra que estes textos não são estranhos às preocupações mais centrais do pensamento de Benjamin, não são marginais, portanto, como também, por meio deles, expõe a importância da questão da linguagem para o próprio Benjamin, dando continuidade a uma reflexão que ele vinha fazendo desde 1916, em "Sobre a linguagem em geral e a linguagem do homem". Questão que se apresenta mediada pela questão da capacidade mimética, a qual, por sua vez, introduz profunda modificação no modo da relação entre o homem (agora sujeito) e as coisas, relação de aproximação, que redunda num saber que preserva o que há de "sensível", de propriamente "material" nas coisas, no mundo.

Entretanto, do ponto de vista propriamente teórico, o que esta resenha nos apresenta de importante, é justamente a possibilidade de compreendermos a ideia de uma "iluminação profana", que aparece no texto sobre o surrealismo de 1929, concomitante ao texto sobre a imagem de Proust, à Rua de mão única, aos textos sobre crianças e brinquedos, assim como aos primeiros esboços e anotações do Passagen-Werk. Esta ideia permite a Jeanne Marie, mais uma vez, reafirmar a importância da mística, assim como a especificidade do "materialismo" benjaminiano. Conforme já me referi acima, ela nos fala de uma "transfiguração", pensando certamente na palavra alemã Verklärung. Ou seja, "transfigurar", criar novas figuras a partir de figuras já existentes, sem que estas desapareçam por inteiro, parece ser o melhor modo de dizer tanto a relação "sensível", sensual, corpórea que estabelecemos com as coisas por meio da capacidade mimética, como também a ideia de criação artística, a qual, pelo menos desde o jovem Nietzsche, a ideia de "transfiguração" está vinculada. "Se prosseguirmos no caminho aberto por Nietzsche, veremos que nele, em especial em $O$ nascimento da tragédia, a ideia de "transfiguração" é uma espécie de derivada do que Goethe chamou de "jogo artístico" (CHAVES, 2012), ${ }^{20}$ como um tipo de pacto que se estabelece entre o autor e o público, um pacto semelhante ao existente entre a criança e seus brinquedos: trata-se sempre de um spielen, de um jogar/brincar, em que as peças podem ser deslocadas, transpostas, compondo diferentes figuras, num constante exercício do que Benjamin chama de "capacidade mimética", ou seja, obedecendo a uma lógica sempre ditada por esse embate corpóreo com o mundo das coisas e que os procedimentos formais das vanguardas estéticas, tais como a montagem no cinema russo ou as colagens no surrealismo ou no cubismo mostravam à exaustão. Ora, com

Cadernos Benjaminianos, Número especial, Belo Horizonte, 2013, página 13-25 
isso, da mesma forma que o jovem Nietzsche, Benjamin pode escapar da noção de mimesis como "imitação" ou ainda "reprodução fiel" das coisas. Mas também, do materialismo metafísico ou ainda do materialismo vulgar, que estabelecia esta mesma ligação por meio da ideia de "reflexo".

Entretanto, qual transfiguração, exatamente, a experiência com as drogas (mas não só com elas) nos permitiria compreender? É aquela operada pelo que Benjamin chama de "iluminação profana", ou seja, "a que transporta - nos diz Jeanne Marie para a análise do mundo material a clarividência da iluminação religiosa mística". ${ }^{21}$ Assim sendo, esse processo transfigurador, processo revolucionário, reuniria, num único momento ou ainda num único exercício, "as forças da mística e a fidelidade cuidadosa à multiplicidade da matéria"22. Com esta afirmação de Jeanne Marie, podemos fechar este breve estudo sobre estes seus três primeiros textos sobre Benjamin publicados no Brasil (até onde sei), para destacar a "característica", a marca pela qual ele se tornou reconhecível para mim: impossibilidade de estabelecer uma separação absoluta e radical entre a juventude e a maturidade, o judaísmo e o materialismo, o conceito e o corpo.

Numa passagem bastante conhecida da Infância berlinense por volta de 1900, mais exatamente no tableau "Mendigos e prostitutas", Benjamin conta as suas tentativas de se subtrair ao controle da mãe, ficando, por exemplo, "meio passo atrás", quando saía com ela a passeio ou para ir às compras. Ele diz dever a essa "resistência sonhadora", aos pequenos atos de "sabotagem" que daí resultavam, muitas de suas descobertas. A mãe ficava desesperada, diz ele. Vemos como a figura clássica da mãe judia, matriarca dominadora, reaparece aqui, mesmo que ela não fosse ortodoxa, ao contrário do pai, pois frequentava a sinagoga reformada (o próprio Benjamin alude a isso em outro tableau de Infância berlinense, "O despertar do sexo"). A "mãe suíça", ao contrário, sempre preferiu que seu "filho" tentasse encontrar não só entre ele e ela, mas entre ele e o mundo, a "distância certa".

\section{Referências}

ADORNO, Theodor. Charakteristik Walter Benjamins. In: Über Walter Benjamin (1950). Frankfurt: Suhrkamp, 1990.

ADORNO, Theodor. "Caracterização de Walter Benjamin". In: Theodor W. Adorno. Sociologia. São Paulo: Ática, 1986.

BENJAMIN, Walter. Gesammelte Schriften. Frankfurt: Suhrkamp, 1992, Band II-1.

BENJAMIN, Walter. Magia e técnica, arte e política. São Paulo: Brasiliense, 1985. (Obras escolhidas, v. I)

CHAVES, Ernani. "Êxtase e jogo estético: a propósito de $O$ nascimento da tragédia". Perspectiva filosófica, v. 1, n. 37, 2012.

GAGNEBIN, Jeanne Marie. A propósito do conceito de crítica de Walter Benjamin. Discurso, São Paulo, v. 13, 1980, p. 219-230.

GAGNEBIN, Jeanne Marie. As drogas de Walter Benjamin: Palavras como vinho. Leia Livros, Ano VII, nº 69, Junho de 1984.

GAGNEBIN, Jeanne Marie. Les bois, les cendres, la flamme: de la critique chez Walter Benjamin. Les cahiers de l'Herne. Paris: Éditions de l'Herne, 2013.

GAGNEBIN, Jeanne Marie. Os cacos da história. São Paulo: Brasiliense, 1982.

OTTE, Georg. Entre a mediação e a exposição - o idioleto de Walter Benjamin. Cadernos Benjaminianos, número especial, Belo Horizonte, 2013.

PRESSLER, Günter Karl. Benjamin, Brasil: a recepção de Benjamin, de 1960 a 2005 um estudo sobre a formação da intelectualidade brasileira. São Paulo: Annablume, 2006.

Cadernos Benjaminianos, Número especial, Belo Horizonte, 2013, página 13-25 


\section{Notas}

${ }^{1}$ ADORNO, Charakteristik Walter Benjamins, p. 9.

${ }^{2}$ No final de junho de 1981, Nelson Brissac Peixoto defendeu a primeira dissertação de mestrado da PUC/SP. Jeanne Marie, juntamente com Paulo Arantes, participou da Banca. $\mathrm{O}$ orientador era Bento Prado Junior. Dois dias antes, saudoso de Belém, viajei de férias e perdi a oportunidade ímpar de assistir a um debate acerca do pensamento de Benjamin, que deu muito o que falar entre a plateia que lá esteve.

${ }^{3}$ Foi apenas em 1988, que assisti, pela primeira vez, na mesma PUC de São Paulo, a um curso de Jeanne Marie sobre Benjamin. Lembro que, por falta de energia elétrica, terminei meu seminário sobre o capítulo sobre Benjamin do livro Redenção e utopia, de Michel Löwy, à luz de velas.

${ }^{4} \mathrm{O}$ trabalho de referência para a recepção brasileira de Benjamin continua sendo o de PRESSLER (2006). O que não significa, evidentemente, que estejamos sempre de acordo tanto com os procedimentos metodológicos quanto com as análises efetuadas por este autor.

${ }^{5}$ GAGNEBIN, A propósito do conceito de crítica de Walter Benjamin, p. 222.

${ }^{6}$ Ibidem.

${ }^{7}$ GAGNEBIN, Les bois, les cendres, la flamme: de la critique chez Walter Benjamin.

${ }^{8}$ GAGNEBIN, A propósito do conceito de crítica de Walter Benjamin, p. 219.

${ }^{9}$ Ibidem, p. 219-220.

${ }^{10}$ Ibidem, p. 219-224.

${ }^{11}$ Ibidem, p. 219-224.

${ }^{12}$ OTTE, Entre a mediação e a exposição.

${ }^{13}$ GAGNEBIN, Os cacos da história, p. 24-40.

14 Ibidem, p. 38.

${ }^{15}$ Ibidem, p. 39.

16 "Leia Livros" circulou entre agosto de 1980 a abril de 1988. No final, era publicado pela Editora Joruês e foi importante veículo de divulgação da literatura brasileira e estrangeira, principalmente na forma de resenhas. Ver a respeito: http://www.cedap.assis.unesp.br/cat_periodicos/popup3/leia_livros.html. Acesso em 26/02/2014.

${ }^{17}$ GAGNEBIN, As drogas de Walter Benjamin, p. 7.

${ }^{18}$ Ibidem.

${ }^{19}$ A referência a Nietzsche não é arbitrária, uma vez que no ensaio sobre o surrealismo, ele é citado, ao lado de Hebel, Büchner e Rimbaud, como uma espécie de precursor do "materialismo antropológico" presente na "experiência dos surrealistas", oposto ao materialismo metafísico de Vogt e Bukarin (BENJAMIN, 1992, p. 309; 1985, p. 35).

${ }^{20}$ CHAVES, Êxtase e jogo estético, p. 93.

${ }^{21}$ GAGNEBIN, As drogas de Walter Benjamin, p. 7.

${ }^{22}$ Ibidem. 